\title{
BAJU HAZMAT UNESA UNTUK GARDA TERDEPAN PENANGANAN COVID-19
}

\author{
Oleh: \\ Indarti ${ }^{1}$, Urip Wahyuningsih"2, Yulistiana ${ }^{3}$, Yuhri Inang Prihatina ${ }^{4}$, Imami Arum Tri Rahayu ${ }^{5}$, \\ Peppy Mayasarí
}

Universitas Negeri Surabaya

indarti@unesa.ac.id

\begin{abstract}
Abstrak
Pencegahan penyebaran infeksi virus COVID-19 pasien ke petugas bergantung pada penggunaan alat pelindung diri (APD), salah satunya baju hazmat. Dokter serta tenaga medis lainnya merupakan garda terdepan yang menangani penyakit COVID-19, sehingga kebutuhan APD adalah paling penting bagi mereka. Untuk melindungi tenaga medis dari virus dalam ruangan serta mencegah virus tersebut keluar ruangan, para tenaga medis harus mengganti APD setiap kali menangani pasien di ruangan yang berbeda. Sehingga APD yang berupa baju (hazmat), masker, sarung tangan dan penutup kepala digunakan sering hanya sekali pakai. Tujuan kegiatan PkM ini adalah untuk menyumbangkan baju hazmat pada tenaga medis yang merupakan garda terdepan yang menangani virus COVID-19. Dalam kegiatan PkM ini, metode yang digunakan adalah pembuatan dan penyaluran alat pelindung diri (APD) berupa hazmat untuk tenaga medis di Rumah Sakit. Tim kami dari prodi Tata Busana UNESA, mendesain alternatif baju hazmat yang terbuat dari kain spundbond polypropylene dengan ketebalan 75 gsm, yang ramah lingkungan, coating waterproof, dan breathable sehingga lebih nyaman dipakai oleh tenaga medis. Kelebihan dari non-woven ini antara lain dapat menyaring udara, anti bakteri, ramah lingkungan, tahan kelembaban air. Sebanyak 250 baju hazmat telah disumbangkan ke beberapa rumah sakit di Surabaya dan sekitarnya bersam produk-produk hasil dari PkM kelompok lain oleh tim Unesa Crisis Center.
\end{abstract}

Kata Kunci: $A P D$, baju hazmat, COVID-19, spundbond polypropylene

\begin{abstract}
Prevention of the spread of the patient's COVID-19 virus infection to officers depends on the use of personal protective equipment (PPE), one of which is the hazmat suit. Doctors and other medical personnel are at the forefront of dealing with COVID-19, so the need for PPE is the most important for them. To protect medical personnel from viruses in the room and prevent the virus from leaving the room, medical personnel must change PPE each time they treat patients in different rooms. So that PPE in the form of suits (hazmat), masks, gloves and headgear is often used only once. The purpose of this community engagement activity is to donate hazmat suits to medical personnel who are at the forefront of dealing with the COVID-19 virus. In this activity, the method used is the productio and distribution of personal protective equipment (PPE) in the form of hazmat for medical personnel at the hospital. Our team from the UNESA Fashion Design study program designed an alternative hazmat suit made of spundbond polypropylene with a thickness of $75 \mathrm{gsm}$, which is environmentally friendly, waterproof coating, and breathable so it is more comfortable for medical personnel to wear. The advantages of this non-woven, among others, can filter air, anti-bacteria, environmentally friendly, moisture resistance. A total of 250 hazmat suits have been donated to several hospitals in Surabaya and its surroundings along with other products from other community engagement groups by the Unesa Crisis Center team.
\end{abstract}

Keywords: PPE, hazmat suit, COVID-19, spundbond polypropylene

\section{PENDAHULUAN}

Pandemi COVID-19 adalah salah satu tantangan global yang melampau batas-batas wilayah, politik, ideologis, agama, budaya, 
adan akademik (Huang dkk, 2010). Telah kita ketahui bersama bahwa corona virus mulai terdeteksi di Wuhan, provinsi Hubei di Negara China. Virus corona merupakan penyakit virus yang ditularkan dari hewan ke manusia, yang sebagian besar seperti flu biasa. COVID-19 sangat mudah menyebar dari orang ke orang karena ada peningkatan eksponensial, dan virus ini disebarkan oleh wisatawan China ke negar-negara lain sehingga WHO menyatakan epidemi sebagai Global Health Emergency pada tanggal 30 Januari 2020 (Holland, Zaloga, \& Friderici, 2020). COVID-19 yang mengiveksi pernafasan dengan cepat berkembang menjadi pandemi global hanya dalam waktu 2 bulan. Sehingga pada tanggal 11 Maret 2020 direktur jenderal WHO menetapkan sebagai pandemi, yang tingkat penyebaran dan keparahan yang mengkhawatirkan (Bedford dkk, 2020).

Menurut Huang dkk (2020) penularan penyakit pernafasan seperti influenza, SARS, MERS, dan COVID-19 dimulai dari cairan tetesan pernafasan orang yang terinfeksi melalui batuk, bersin, dan bahkan potensi berbicara. Tetesan tersebut mongering pada berbagai objek (gagang pintu, permukaan meja, pegangan tangan, layar sentuh, dII) dan berpotensi menjadi menular, bahkan beberapa melayang di udara dalam jangka waktu tertentu. Untuk memblokir dan memutuskan penularan tersebut, dapat dilakukan dengan berbagai cara, antara lain: (a) mengisolasi pasien yang terinfeksi atau mengurangi penyebaran tetesan cairan pernafasan mereka, (b) membersihkan objek dan permukaan (c) menyaring udara yang berpotensi terkontaminasi, (d) mencuci tangan sesering mungkin, (e) membangun kebiasaan higienis pribadi yang lebih baik, (f) mengenakan personal protection equipment (PPE) atau alat pelindung diri (APD).

Kelangkaan alat pelindung diri (APD) mulai terjadi di tengah pademi COVID-19. Ketika penyebaran pandemic COVID-19 semakin cepat, system perawatan kesehatan global menjadi kewalahan dengan jumlah pasien. Pencegahan penyebaran infeksi pasien ke petugas bergantung pada penggunaan alat pelindung diri (APD). APD yang semula ada dimana-mana dan sekali pakai di Rumah Sakit, sekarang menjadi komoditas langka dan berharga (Livingston, Desai \& Berkwits, 2020).

Dokter dan tenaga medis merupakan garda terdepan yang menangani penyakit COVID-19, sehingga kebutuhan APD adalah paling penting bagi mereka. Untuk melindungi tenaga medis dari virus dalam ruangan serta mencegah virus tersebut keluar ruangan, para tenaga medis harus mengganti APD setiap kali menangani pasien di ruangan yang berbeda. Sehingga APD yang berupa baju (hazmat), masker, sarung tangan dan penutup kepala digunakan sekali pakai dan dibuang (cnnindonesia.com). Untuk itu dalam kegiatan PKM ini kami membuat desain alternative untuk APD dari bahan spundbond polypropylene. Tujuan kegiatan PkM ini adalah untuk membuat dan menyumbangkan baju hazmat pada tenaga medis yang merupakan garda terdepan yang menangani virus COVID-19. Kami mendesain dan memproduksi beberapa baju hazmat dari bahan alternative yang murah, waterproof, breathable dan ramah lingkungan yaitu spundbond polypropylene dengan ketebalan $75 \mathrm{gsm}$ yang cukup efektif untuk melindungi tenaga medis dari paparan visrus COVID-19.

\section{METODE}

Dalam kegiatan PkM ini, metode yang digunakan adalah pembuatan desain, produksi dan distribusi alat pelindung diri (APD) berupa baju hazmat untuk tenaga medis di Rumah Sakit.

\section{Desain Baju Hazmat}

Tim kami dari prodi Tata Busana UNESA, mendesain alternatif baju hazmat yang terbuat dari kain spundbond polypropylene dengan ketebalan $75 \mathrm{gsm}$, yang ramah lingkungan, coating waterproof, dan breathable sehingga lebih nyaman dipakai oleh tenaga medis. Kelebihan dari non-woven ini antara lain dapat menyaring udara, anti bakteri, ramah lingkungan, dan tahan kelembaban air.

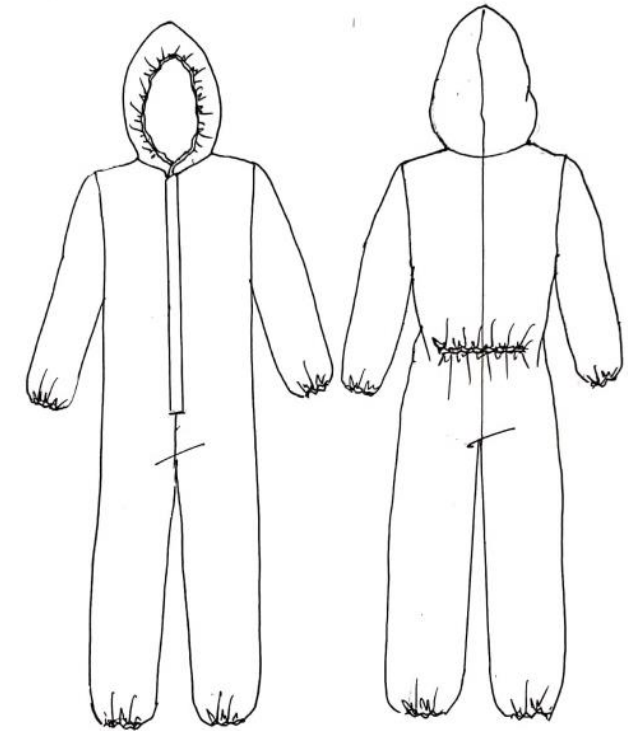




\section{Gambar 1. Desain Baju Hazmat}

Gambar 1 adalah desain baju hazmat yang terdapat elastik hoodie pada bagian muka, pergelangan tangan, pergelangan kaki, dan pinggang belakang. Opening berupa retsleting sepanjang tengah muka. Baju hazmat di desain dengan dua ukuran/size yaitu medium (M) untuk tenaga medis wanita dan extra large $(\mathrm{XXL})$ untuk tenaga medis pria.

\section{Produksi Baju Hazmat}

Kegiatan ini sangat penting dalam ikut membantu pencegahan COVID-19 pada tenaga medis, yang merupakan garda terdepan dalam menanggulangi pandemi COVID-19 yang semakin meresahkan. Proses produksi baju hazmat telah bekerjasama dengan UKM jasa jahit rumahan di wilayah Surabaya dan Sidoarjo. Dengan melibatkan UKM jasa jahit juga berarti membantu UKM dalam menghadapi kondisi ekonomi pada saat pandemi seperti ini. Industri pakaian termasuk salah satu industri yang paling terdampak pada masa pandemi, masyarakat menghindari aktivitas diluar rumah sehingga tidak membutuhkan pakaian baru.

Industri pakaian dapat bertahan dengan memanfaatkan kesempatan krisis ini untuk menjahit pakaian hazmat. Banyak industri konveksi karena tidak ada order pakaian, mereka beralih untuk menjahit pakaian hazmat. Kegiatan PKM ini juga merupakan salah satu upaya memberikan pekerjaan pada jasa penjahit rumahan. Selain kegiatan bermanfaat untuk tenaga medis, kegiatan juga bermanfaat untuk UKM jasa jahit di wilayah sekitar.

\section{Distribusi Baju Hazmat}

Kegiatan Pengabdian kepada Masyarakat ini dibawah koordinasi LPPM Unesa tahun 2020 dengan tema khusus penanggulangan COVID-19. Kami juga bekerja di bawah koordinasi "UNESA Crisis Centre" (UCC) yang membagikan baju hazmat dan barang-barang lain yang dibutuhkan pihak Rumah Sakit. Hasil produksi baju hazmat telah didistribusikan ke beberapa Rumah Sakit di wilayah Surabaya dan Kota lain di Jawa Timur oleh tim Unesa Crisis Centre (UCC) pada saat pamdemi gelombang pertama sekitar bulan Mei 2020. Proses produksi dilakukan dengan bekerjasama dengan industri konveksi kecil di Surabaya dan Sidoarjo untuk membuat baju hazmat dengan target waktu yang cepat, mengingat keberadaan baju hazmat sangat dibutuhkan saat itu.

\section{HASIL DAN PEMBAHASAN}

Kegiatan pengabdian ini telah dilaksanakan dengan baik. Proses produksi baju hazmat telah bekerjasama dengan UKM jasa jahit di wilayah Surabaya dan Sidoarjo dan dalam waktu dua bulan telah menghasilkan 250 baju hazmat size $L$ warna shocking pink dan size XXL warna peach orange. Baju hazmat ini terbuat dari kain spundbond polypropylene dengan ketebalan $75 \mathrm{gsm}$, yang ramah lingkungan, coating waterproof, dan breathable sehingga lebih nyaman dipakai oleh tenaga medis. Ketebalan kain tersebut (75 gsm) adalah paling ideal untuk pembuatan baju hazmat, karena jika terlalu tipis tingkat perlindungannya juga kurang, karena cairan bisa saja tembus ke kulit. Kelebihan dari nonwoven ini antara lain dapat menyaring udara, anti bakteri, ramah lingkungan, tahan kelembaban air.

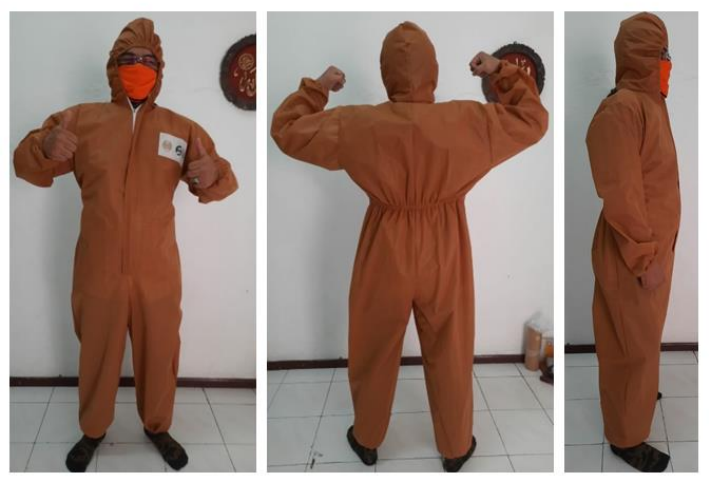

Gambar 2. Hasil Jadi Baju Hazmat Tampak dari Depan, Belakang, dan Samping

Hasil jadi baju hazmat tampak pada Gambar 2, berupa baju overall one piece yang melindungi tubuh dari kepala hingga kaki dengan size XXL untuk pria. Terdapat opening berupa retsleting dibagian depan, karet elastik pada pergelangan tangan dan kaki supaya rapat, serta bagian kepala depan (muka) sehingga pas menutup kepala dan bagian muka tetap terlihat. Elastik juga diterapkan pada bagian pinggang belakang sehingga meskipun baju hazmat oversizel longgar, namun tetap rapi jika dipakai. Selain size XXL kami juga membuat size L warna shocking pink yang cerah yang cocok untuk tenaga medis wanita (gambar 3). Kedua desain baju hazmat tersebut terdapat logo 
Unesa dan UCC dengan teknik sablon dan dijahitkan pada bagian dada sebelah kiri.

Baju hazmat yang telah kami produksi ini merupakan disposable APD, jadi idealnya bisa dipakai sekali pakai saja kemudian dibuang, kalaupun bisa dicuci hanya mampu bertahan 2 sampai 3 kali pencucian. Karena bahannya didesain mudah hancur sehingga tidak mencemari lingkungan dalam waktu yang lama. Kain spundbond polypropylene merupakan kain non tenun yang struktur dan sifatnya dipengaruhi kondisi ekstrusi, sifatnya merupakan hasil dari susunan jaringan dan kondisi ikatannya (Nanjundappa \& Bhat, 2005). Bahan spunbond terdiri dari filamen dengan panjang tak terhingga dan, oleh karena itu, kurang rentan terhadap abrasi (Leucker, Amtmann, \& Schubert, 2018).

Kain spunbond juga termasuk cukup nyaman dipakai, karena struktur kain yang breathable. Bahan ini mengandung kapas (Vincent dkk, 2016). Kain spundbond menunjukkan kekuatan dan kekakuan yang lebih rendah dari pada kain tenun, tetapi penyerapan energi dan kemampuannya untuk berubah bentuk selama pemuatan dan deformasi jauh lebih besar daripada kain tenun (Kansal, 2016).

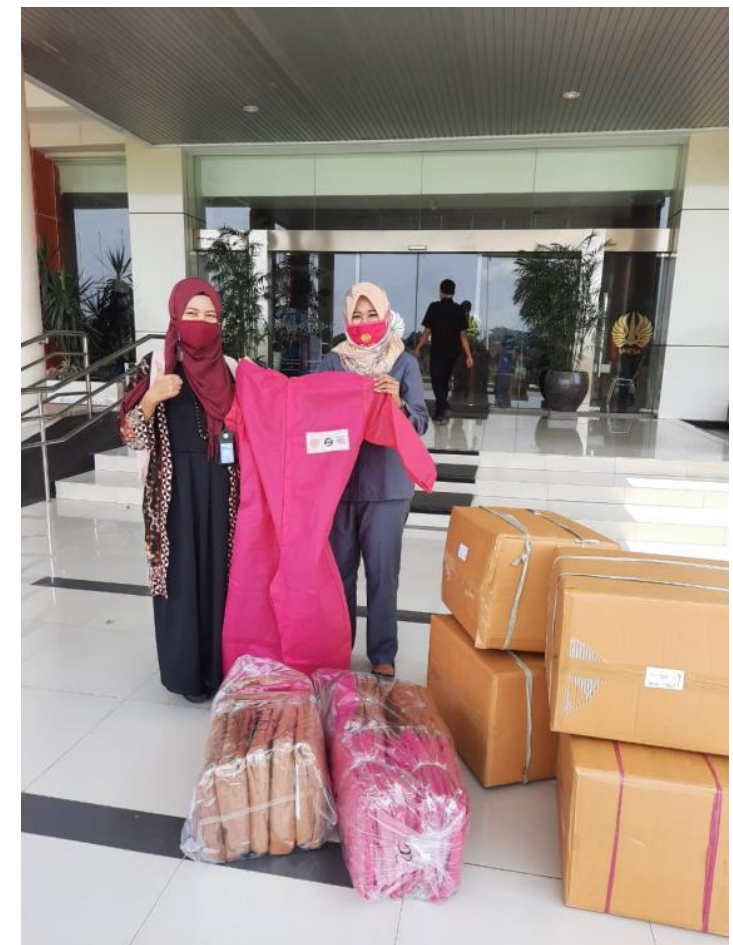

Gambar 3. Proses Pengiriman Barang ke LPPM Unesa

Baju hazmat telah kami serahkan ke Unesa Crisis Center (UCC) dalam dua tahap.
Tahap 1 telah kami serahkan pada tanggal 23 April 2020 sebanyak 100 baju dan pada tanggal 4 Mei 2020 sebanyak 250 baju. Gambar 3 adalah proses pengiriman barang tahap 2 ke LPPM Unesa. Berdasarkan informasi yang kami peroleh, baju hazmat tersebut oleh tim UCC Unesa telah didistribusika di beberapa Rumah Sakit antara lain: RSUD Ibnu Sina Gresik, RSUD Jombang, RSUD Madiun, RSUD Kediri, RSUD Nganjuk, RSUD Lamongan, RSUD Trenggalek, RSUD Dr. Soetomo Surabaya, dan RSI Jemursari Surabaya, bersama produk-produk lain dari kegiatan PkM penugasan Covid-19 ini.

Untuk kondisi pandemi saat ini yang belum juga mengalami penurunan, penggunaan baju hazmat sebagai salah satu alat pelindung diri (APD) masih sangat diperlukan oleh tenaga medis. Penggunaan disposable APD akan berkurang, pemilihan bahan yang bisa dipakai berkali-kali akan menjadi pilihan utama. Dengan alasan efekivitas, maka ke depan tuntutan bahan APD harus lebih tahan lama dan bisa cuci sehingga dapat dipakai berulang-ulang. Hal ini akan mengurangi biaya persediaan APD bagi manajemen rumah sakit.

\section{SIMPULAN DAN SARAN}

\section{Simpulan}

- Kegiatan pelaksanaan pengabdian kepada masyarakat (PkM) telah dilaksanakan dalam waktu yang sangat tepat pada bulan April dan Mei 2020 ketika sedang memuncaknya pandemi COVID-19 di Indonesia

- Melalui kegiatan PkM ini Unesa telah membantu masyarakat utamanya tenaga medis yang merupakan garda terdepan dalam menangani pandemi COVID-19

- Baju hazmat dalam PkM ini merupakan disposable APD yang terbuat dari spundbond polypropylene dengan ketebalan $75 \mathrm{gsm}$ yang ramah lingkungan, coating waterproof, dan breathable sehingga lebih nyaman dipakai oleh tenaga medis.

\section{Saran}

Melihat kondisi saat ini dimana pandemi COVID-19 masih belum mengalami penurunan, kebutuhan baju hazmat untuk tenaga medis masih tinggi. Oleh karena itu perlu dilakukan penelitian dan perancangan 
desain hazmat dari bahan yang tahan lama, dapat dicuci dan dipakai berkali-kali, dan desain yang aman dan nyaman digunakan. Selama virus COVID-19 masih ada disekitar kita, kedepan perlu kegiatan PkM lanjutan yang masih menangani penyebaran virus COVID-19.

\section{DAFTAR PUSTAKA}

Bedford, J., Enria, D., Giesecke, J., Heymann, D. L., Ihekweazu, C., Kobinger, G., ... \& Ungchusak, K. (2020). COVID-19: towards controlling of a pandemic. The Lancet.

Cheung, J. C. H., Ho, L. T., Cheng, J. V., Cham, E. Y. K., \& Lam, K. N. (2020). Staff safety during emergency airway management for COVID-19 in Hong Kong. The Lancet. Respiratory Medicine, 8(4), e19.

Kansal, H. (2016). Experimental investigation of properties of polypropylene and nonwoven spunbond fabric. IOSR Journal of Polymer and Textile Engineering (IOSRJPTE), 3(5), 8-14.

Livingston, E., Desai, A., \& Berkwits, M. (2020). Sourcing personal protective equipment during the COVID-19 pandemic. JAMA.

Holland, M., Zaloga, D. J., \& Friderici, C. S. (2020). COVID-19 Personal Protective Equipment (PPE) for the emergency physician. Visual Journal of Emergency Medicine, 19, 100740.
Huang, H., Fan, C., Li, M., Nie, H. L., Wang, F. B., Wang, H., ... \& Huang, J. (2020). COVID-19: A Call for Physical Scientists and Engineers. ACS nano.

Leucker, K., Amtmann, J., \& Schubert, D. W. (2018). Novel objective test method for the abrasion and pilling behaviour of low basis weight spunbond polypropylene nonwovens. Polymer Testing, 69, 175181.

Nanjundappa, R., \& Bhat, G. S. (2005). Effect of processing conditions on the structure and properties of polypropylene spunbond fabrics. Journal of applied polymer science, 98(6), 2355-2364.

Vincent Edwards, J., Mao, N., Russell, S., Carus, E., Condon, B., Hinchliffe, D., ... \& Wang, Y. (2016). Fluid handling and fabric handle profiles of hydroentangled greige cotton and spunbond polypropylene nonwoven topsheets. Proceedings of the Institution of Mechanical Engineers, Part L: Journal of Materials: Design and Applications, 230(4), 847-859.

World Health Organization. (2020). Rational use of personal protective equipment for coronavirus disease (COVID-19): interim guidance, 27 February 2020 (No. WHO/2019-nCov/IPCPPE_use/2020.1). World Health Organization.

https://www.cnnindonesia.com/gayahidup/20200323151822-255486110/alasan-penggunaan-apd-tenagamedis-harus-sekali-pakai 